\title{
Dairy Supply Chain Management and Critical an Investigations on Dairy Informal Channel Partners in Pakistan
}

\author{
ZiaUllah Muhammad ${ }^{1}$, Shumaila Naz Akhter ${ }^{2}$, Muhammad Kafayat Ullah ${ }^{3}$ \\ ${ }^{I}$ Ph.D Scholar-School of Management and Economics, University of Electronic Science and Technology of \\ China \\ ${ }^{2}$ Virtual University of Pakistan \\ ${ }^{3}$ Al-Haseeb Public High School, Block No. 39 Dera Ghazi Khan, Pakistan
}

\begin{abstract}
The specific objective of this paper is to present the importance of dairy supply chain management and to illustrate the current practices of diary supply chain in Pakistan. Specifically, to shed light on the production and consumption patterns in developing world mainly based on the FAO and Pakistan Economic Survey data. World milk production was 730 million tonnes in 2011 and it is expected to increase in the future. Importantly, 80 percent consumption of milk has handled by informal traders in the developing countries and this community has 98 percent share in Pakistani milk supply chain. Supply chain disruption has become critical issue that is based on informal channel bargaining power and information barriers. Currently, India, China and Pakistan have been standing in the list of four leading producers of milk worldwide. However, milk producers and consumers both have been facing economic, social and health losses due to the informal dairy supply chain partners.
\end{abstract}

Keywords: Dairy supply chain, milk production, gawalla, adulteration, agri-food supply chain

\section{Introduction}

Predominantly agricultural research interest has been dramatically increasing towards supply chain management because of recent years certain significant changes that are affecting the industry. Rapid development of globalization, shifting consumer demand, dismantling state support schemes and technological progress has so caused declaration of industrialization of agriculture [1]. In fact firms no longer competitively can survive in isolation of their suppliers, customers and other entities of the supply chain. The term supply chain management arises publically as used by Keith Oliver in its interview to financial times in 1982. It has gained prominence importance and began to use by operation managers in their titles as it consistently increased regularity in late 1990. Supply chain management (SCM) deals with the total flow of materials from suppliers to end users [2]. SCM is an integrative philosophy to manage the total flow of distribution from supplier to ultimate end users [3]. Lambert and Cooper defined Supply chain management (SCM) as an integration of key business processes from end user through original suppliers that provides products, services and information that add value for customers and other stakeholders [4]. Particularly this sort of supply chain integration among partners has gain benefits increased revenue \& inventory turnover, cost reduction [5,6], reduced order cycle and greater productivity availability $[7,8,9]$. Additionally SCM can improve market responsiveness, reduction in logistic cost, added economic value and optimum utilization of capital cost $[10,11,12]$. Substantially, SCM has been considered one of the critical areas in the development of agriculture industry to meet the global market demand [13].

Hence food supply chain encompasses organizations which are responsible for the production and distribution of vegetable and animal based products [14]. There are various common partners of the food supply chain such as producer or grower, wholesaler, retailer, food industry and consumer market. Agri-food supply chains are quite complicated as it involved multiple multifaceted firms that usually working collectively within certain specific industry sectors [18]. Food supply chain network is complex and that comprises on different companies which strategically collaborate in one or more areas while preserving their own identity and autonomy [19]. Specifically it is believed that agricultural products have been declared important in respect of consumption and monetary value [20]. Consequently, partners of the agricultural product supply chain have been changing from family based small scale independent firms to more tightly integrated, more dependent players of the whole value chain of production and distribution [21].Therefore, SCM literature focuses on the need of collaboration among successive stakeholders of the supply chain from producer or grower to end consumers in order to superior satisfaction of consumer demand at lowest cost [15,16]. Perhaps, philosophy of SCM is to identify and breakdown the different sorts of barriers which may exist between different links in the chain in order to ultimately brought reduction in cost and to accomplish substantial improvement in service level [17]. It is suggested that agri-supply chain is complicated due to hybrid nature of an organization. It is neither 
firm nor market. In fact processing and distribution sectors have become concentrated during last few decades [23].

This study entirely focused on dairy supply chain especially in developing countries. Specifically, we defined dairy as it comprises the individual or firms that involved in milk production, transportation, processing (packaging \& storage) and delivery of milk products to final consumer through addition of maximum value at lowest possible cost. There are evidences that agricultural supply chain has comprises many issues such as asymmetrical information, adverse select, free rider, uncertainty, specific investment, bargaining power, incomplete contract and so on. It is investigated that asymmetric information between dairy farmers and milk processors leads to market failure [22]. While the SCM literature often seems to assume that a rising tide lifts all boats... a chain member may exploit its partners for its own gain. [24]. Crook and Combs (2007) found that strong members reap most of the direct benefits, weak members can often gain by building switching costs with strong members, leveraging SCM outside the focal chain, and increasing survival chances [25].

This study has focused on analysis of dairy supply chain in developing countries, its status quo, importance and critical issues that might create some trouble among supply chain partners.

\section{Research Objectives:}

- To explain the current structure of dairy supply chain management

- To explore the critical issues and core activities associated dairy supply chain management

- To examine the informal channel partners (Gawala, Dhodi) roles in dairy supply chain

- To highlight the problem of the dairy supply chain structure

- To identified the critical failure of dairy supply chain

\section{Literature Review}

Especially food and financial crises year 2008 and 2009 has stimulate governments to put more concentration on the value of food and nutrition security as essential components on political stability and socioeconomic development. Dairy industry worldwide has been changing due to more concerns over sustainability, consumers demand and greater efficiency requirements [26]. Substantially, major drivers of livestock products and high valued food items are economic growth, population growth and urbanizations [27, 28]. Thus Asians diary demand has been expanding rapidly [27]. Consequently in advanced countries, demand of fresh and nutritious food and shelf life has been significantly improved, hence food preservation is continuous fight against microorganisms spoiling food or making it unsafe [29]. It is suggested that dairy sector continuously strive for efficiency due to the price and volume competition in various countries. For this purpose there are five critical issues that might drive changes in dairy sector over next 50 years such as (potential cost of greenhouse gasses, opportunities for biotechnology driven breeding, development of specialized milk, continuous strive for efficiency as commodity value of milk decreases and cost of animal disease eradication) [30]. As demand of milk has been dramatically increasing in the world so dairy sector should continuously looks for innovative methodologies and solutions to address such trends and improved value added through certain mechanisms. During the milk supply chain management, storage of milk is very critical issue and challenge for producer and other trade channel members. Researchers have been investigated that storage circumstance of raw milk can affect the quality, yield, sensory values and shelf life derived dairy products $[31,32]$. Particularly milk storage during collection on farm side improvement means to extension of shelf life and improve safety, these kinds of significant changes in the dairy production stages might occur due to microbial growth [33]. Currently innovative packaging concepts have been introduced due to the customer's requirements for fresher and healthy foods as new retail and distribution practices such as E-commerce, globalization and centralization [34]. In the current era of technological developments, active and intelligent packaging system has been appreciated in developing and developed countries at very large scale and it is helpful to reduce wastage cost and improve agricultural product supply chain integration among diverse located suppliers and customers. Active packaging (AP) trend is useful to improve shelf life, food safety, sensory values and simultaneously maintaining quality standard of packaged food [35]. Similarly intelligent packaging has been performing certain intelligent functions to facilitate decision making about shelf life, food safety and quality through providing information and highlighting potential problems [36].

There are enormous kinds of disruption may occur in the dairy supply chain. Privatization and restructuring of farms, processor, input suppliers and retailing companies caused disruption in the exchange relationships in the dairy chain i.e long payment delays or nonpayment of delivered dairy products. In case of such kind of market behavior Albanian farmers have been decided to sell their milk directly in the urban market and get cash payment. This was the number one business problem in the Central Europe in mid 1990s which has been verified by researcher [37]. Similarly shortage of high quality milk is also another problem and demand for quality may come from public or private standards. There is lacking of appropriate institutions in the dairy industry. Thus private contractual initiatives have emerged to overcome problems that normally processors 
faced through sourcing high quality supplies and though farms have been producing according to the requirements. Particularly a strategy to address these kinds of issues to involved vertical coordination in the dairy supply chain [38].

Bargaining power has been considered quite important element in the dairy sector supply chain management. As this chain consists on multiple chain members that have specific objectives. Thus each partner has unique characteristics that produce power for that partner. Particularly, power creates that chain member influence on the decision making or supply chain activities of others. Generally stronger members can get the more benefits from the supply chain in respect of profit gains from lower cost, enhanced innovative capacity and increased value $[39,40]$. Such stronger member can also benefit through increased bargaining power out of the focal chain. They achieve lower costs through improved economies of scale [41], reduced inventory [40], shorter lead times [41] and lower coordination costs [42]. Recently power has been defined from operation management point of view, according to that view power is based on resources categories such as (finance, human, organization, innovation, technology, finance and production) and power produced in the categories of controls as (pricing, inventory operation, and information, channel or distribution structure). In this way these kinds of power categories has produced power positions of dominated, dominant, interdependent and independent in the structure of supply chain [43].

\section{Research Methodology}

This study is secondary research and mainly based on data base of Food and Agriculture Organization (FAO) and Pakistan Economic Survey. We carried out evaluations, illustrations and extraction of some tendencies in production and consumption of milk on the bases of this data. The main objective of present study is to highlight the importance of dairy supply chain management and its contributions in the industry. Pakistan Economic Survey and FAO data bases provides the most appropriate numbers about the production and consumption of milk at country Pakistan and global level. I have presented tables and figures to review the production and consumption trends of milk in Pakistan. Furthermore, we took insights about diary supply chain practices in Pakistan from Pakistan Dairy Development website. This website data and personal observations have been used to understand the practices of milk supply chain in Pakistan.

\section{Results and Discussions}

It is noticed that dairy farms produced 730 million tonnes milk worldwide during 2011. Milk production has been increasing and it can rise above 794 million tonnes in 2017. Currently in the milk production maximum contributions comes from developing countries such as India is the top milk producing country in the world (110 million tonnes) USA( 85 million tonnes), China (40 million tonnes) while Pakistan produced 34 million tonnes. Pakistan is the fourth largest milk producing country in the world. However, milk production expansion has been increasing in the South Asia since 1970s, while in Africa milk production is quite slow as compared to other world countries. Particularly, milk highest surpluses countries are New Zealand, USA, Germany, Ireland, Australia and France. Similarly world largest milk deficit countries are China, Itly, Russians Federation, Algeria, Mexico and Indonesia. Specifically, China and Russia is the world largest milk importers, whereas European Union's 28 member states, Australia, New Zealand and USA are the world largest exporters of milk and milk products around the globe. In dairy sector about 150 million people are involved in the milk production. According to FAO cow's milk production stood at 620 million tonnes, particularly maximum milk production comes from cow's milk and USA is the largest cow's milk production country (91 MT) and India is the second largest country (54 MT).

Pakistan dairy sector plays a very significant role in the development of national economy and its value of contributions is more than wheat and cotton sectors combined. In fact Pakistan livestock sector contributed $55.4 \%$ to the agricultural value added and about $11.9 \%$ to the gross domestic product (GDP) during fiscal year 2012-13. Milk production contributes in the livelihood, nutrition, and food security. Although world milk production derived from goats, sheep, buffaloes, cows and camels. These are the major species in the Pakistan to producing milk. In the overall world milk production comprises the shares of cows $83 \%$, buffaloes $13 \%$, goats $2 \%$, sheep $1 \%$ and camels contribution are $0.3 \%$. Pakistan livestock population is presented in Table.1

Table.1 Population-Livestock (Millions Nos.)

\begin{tabular}{|l|c|c|c|c|c|c|c|}
\hline Species & $\mathbf{2 0 0 6 - 0 7}$ & $\mathbf{2 0 0 7 - 0 8}$ & $\mathbf{2 0 0 8 - 0 9}$ & $\mathbf{2 0 0 9 - 1 0}$ & $\mathbf{2 0 1 0 - 1 1}$ & $\mathbf{2 0 1 1 - 1 2}$ & $\mathbf{2 0 1 2 - 1 3}$ \\
\hline Cattle & 30.7 & 31.8 & 33.0 & 34.3 & 35.6 & 36.9 & 38.3 \\
\hline Buffaloes & 28.2 & 29.0 & 29.9 & 30.8 & 31.7 & 32.7 & 33.7 \\
\hline Sheep & 26.8 & 27.1 & 27.4 & 27.8 & 28.1 & 28.4 & 28.8 \\
\hline Goat & 55.2 & 56.7 & 58.3 & 59.9 & 61.5 & 63.1 & 64.9 \\
\hline Camels & 0.9 & 1.0 & 1.0 & 1.0 & 1.0 & 1.0 & 1.0 \\
\hline
\end{tabular}




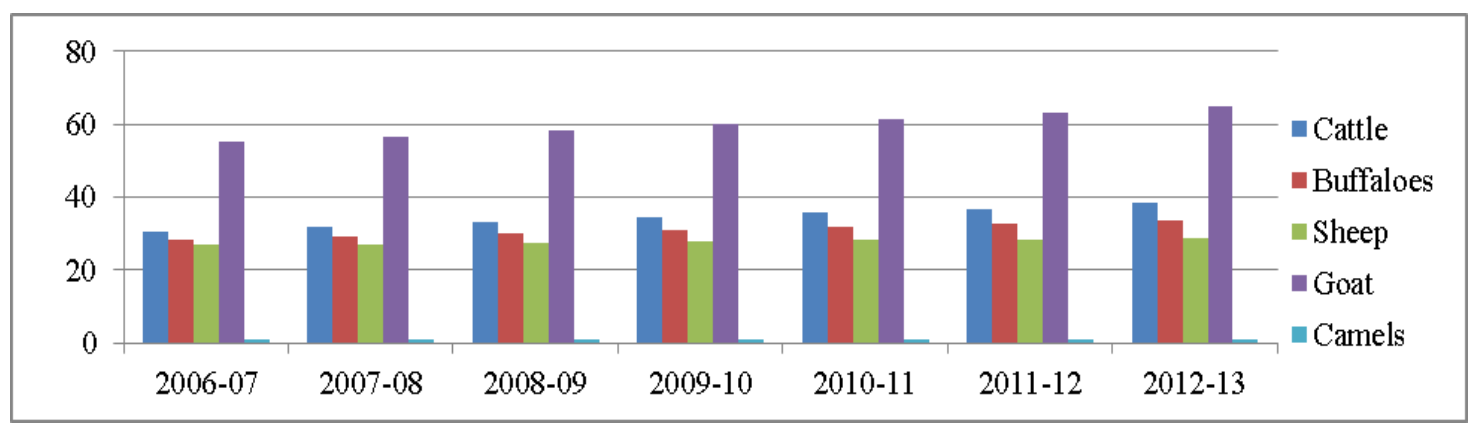

Fig. 1 Population-Livestock 2006-13

Table.2 Milk Production (Tonnes- 000) of Major species in Pakistan 2006-13

\begin{tabular}{|l|l|l|l|l|l|l|c|}
\hline Species & $\mathbf{2 0 0 6 - 0 7}$ & $\mathbf{2 0 0 7 - 0 8}$ & $\mathbf{2 0 0 8 - 0 9}$ & $\mathbf{2 0 0 9 - 1 0}$ & $\mathbf{2 0 1 0 - 1 1}$ & $\mathbf{2 0 1 1 - 1 2}$ & $\mathbf{2 0 1 2 - 1 3}$ \\
\hline $\begin{array}{l}\text { Gross } \\
\text { Production }\end{array}$ & 40,872 & 42,191 & 43,562 & 44,978 & 46,440 & 47,951 & 49,512 \\
\hline Cow & 13,913 & 14,437 & 14,982 & 15,546 & 16,133 & 16,741 & 17,372 \\
\hline Buffaloes & 25,465 & 26,231 & 27,028 & 27,848 & 28,694 & 29,565 & 30,462 \\
\hline Sheep & 35 & 35 & 36 & 36 & 36 & 37 & 37 \\
\hline Goat & 682 & 700 & 719 & 739 & 759 & 879 & 801 \\
\hline Camels & 777 & 787 & 798 & 808 & 818 & 829 & 840 \\
\hline
\end{tabular}

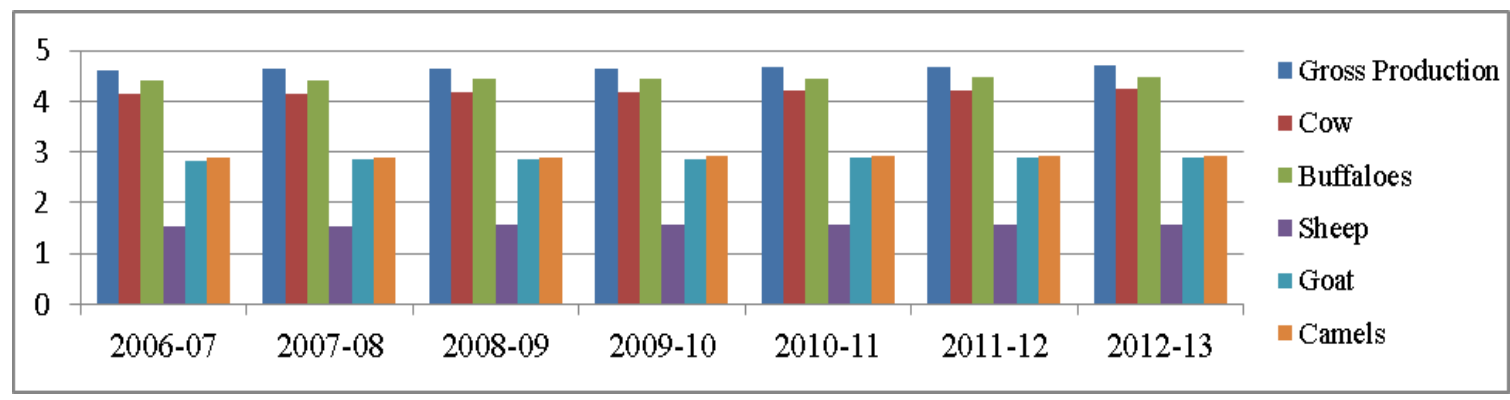

Fig. 2 Milk Production- Major Species 2006-13

Table.3 Milk Consumption (Tonnes-000) of Major Species in Pakistan 2006-13

\begin{tabular}{|l|l|l|l|l|l|l|l|}
\hline Species & $\mathbf{2 0 0 6 - 0 7}$ & $\mathbf{2 0 0 7 - 0 8}$ & $\mathbf{2 0 0 8 - 0 9}$ & $\mathbf{2 0 0 9 - 1 0}$ & $\mathbf{2 0 1 0 - 1 1}$ & $\mathbf{2 0 1 1 - 1 2}$ & $\mathbf{2 0 1 2 - 1 3}$ \\
\hline $\begin{array}{l}\text { Milk Human } \\
\text { Consumption* }\end{array}$ & 32,996 & 34,064 & 35,160 & 36,299 & 37,475 & 38,690 & 39,945 \\
\hline Cow & 11,130 & 11,550 & 11,985 & 12,437 & 12,906 & 13,393 & 13,897 \\
\hline Buffaloes & 20,372 & 20,991 & 21,622 & 22,279 & 22,955 & 23,652 & 24,370 \\
\hline Sheep & 35 & 35 & 36 & 36 & 36 & 37 & 37 \\
\hline Goat & 682 & 700 & 719 & 739 & 759 & 779 & 801 \\
\hline Camels & 777 & 787 & 798 & 808 & 818 & 829 & 840 \\
\hline
\end{tabular}

*Human milk consumption has derived through subtraction of $20 \%$ (15\% transportation \& 5\% in Calving waste)

\section{a. Core Activities of Dairy Supply Chain:}

Dairy supply chain comprises on six core activities such as production, transportation, processing, packaging, storage and consumption. It is required to synchronize these activities of the various dairy supply chain partners. It is challenging phenomenon that Pakistani dairy supply chain core activities has been segregated and there still no any mechanism introduced for integration. Particularly, it is complicated issue to design an efficient, hygienic and economic dairy supply chain for developing countries. There are quite important viable complications existed in the dairy supply chain, firstly it is difficult to establish a sound milk collection and transportation system. Small dairy holders produced little quantities of milk and that are situated in the remote areas. Fig. 3 represented core activities of dairy supply chain. 
Financial Flow

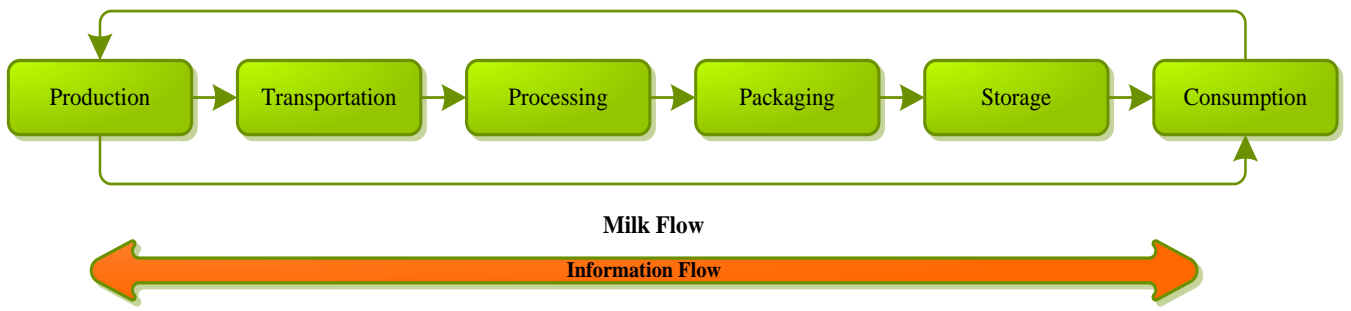

Fig. 3 Activities of Dairy SC

Pakistan dairy supply chain is very complicated, there is about $40 \%$ milk surplus after home consumption, calves suckling and then farmers have just way of indigenous home processing to the urban market. In fact $20 \%$ milk is being wasted in transportation, calving and lack of proper cooling and storage mechanisms. It is estimation that $2 \%$ urban market get milk from formal channel and remaining $98 \%$ get from the informal channel of milkman. Importantly, Pakistani farmers sell their morning timing milk either to the milk collection center, milk trader or milkman and evening milk they consume on their own value added products such as butter, Desi Ghee, yogurt or Lassi. A commercial rural farms sell their surplus milk to milkman (traditionally it is called Gawalla) or deliver at the village milk collection point that are developed by food processing companies (i.e Nestle, Engro Foods etc). While Commercial urban farm are more attractive and they sell their milk directly to consumers on much more attractive price. Generally in Pakistan processing of milk is handled by formal channel or food processing firms. There are different sorts of processed milk such as pasteurized milk, liquid milk, UHT milk in tetra pack. Similarly there are some other processed milk products i.e Chees,Ice cream, Yogurt and Butter. Although, informal channel produces Lassi which is very popular in Pakistan and India. Beside this informal channel used milk for sweets and khoya etc. This formal and informal channel of milk distribution framework of supply chain depicted in Fig.4.

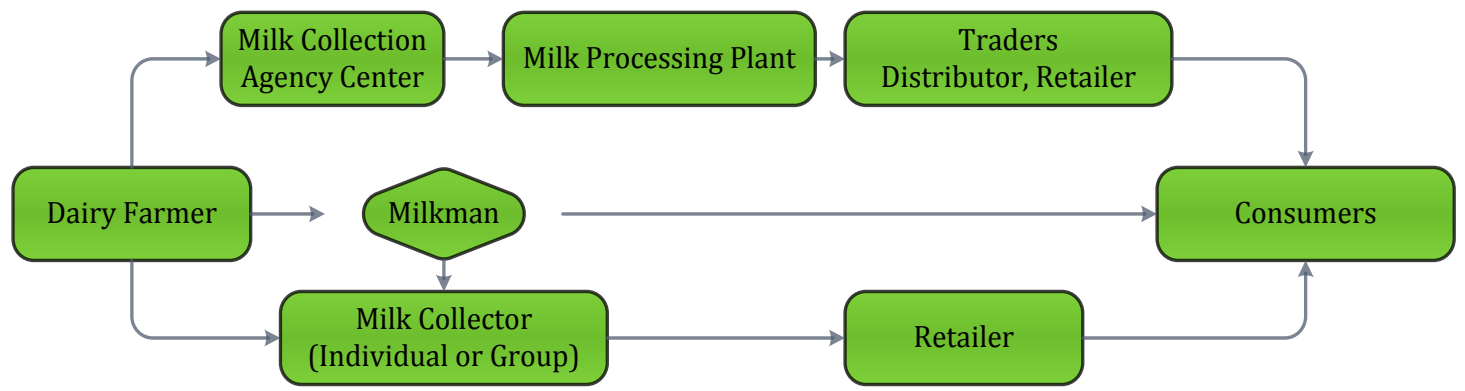

Fig. 4 Traditional Dairy Supply Chain

Milk collectors (Gawala or Dhodi) have been playing important rules in collection, marketing and distribution of Pakistan dairy sector supply chain. Milk Collector community has been increasing rapidly and it crossed a million in number. Generally this community has been divided into three classes such as small milk collector that individuals collect about $200-400 \mathrm{~kg}$ milk per day from various remote areas of Pakistan. It commonly used long term contract or predetermined prices to farmers for their milk. Sometime milk collector makes advanced payment to the formers. Medium milk collectors collect 400-800 kg milk per day but their milk collection strategies are similar with small Gawallas. Large scale milk collector collect 1.5 ton to 3 ton per day and they collect this milk quantity from small or medium Gawallas and sell that milk to retailers or shopkeeper. This community has been greatly involved in the milk adulteration and also exploited to farmers. They have greater bargaining power in the dairy supply chain in respect of finance and information. Dairy supply chain informal channel has unfair advantages over the formal channel and contributing to providing poor quality of milk to detriment of consumers in Pakistan. Specifically, farmers have been suffering losses in the shape of money, wastage of milk and so on. More explanatory structure of milk supply chain is stated beneath in Fig.5. Power phenomenon is not a challenging issue in developing countries but it also existed in developed world. Particularly buyers (i.e supermarket) have different kinds of power such as listing \& slotting fee, delisting or threat of delisting, late payment, below cost selling and promotion of personal brands etc that have negative effects on the performance of suppliers. Meanwhile, buyer's power abuses have this kind of effects on consumers such as loss of choice, push prices, low new products and mislead about sustainability concerns. 


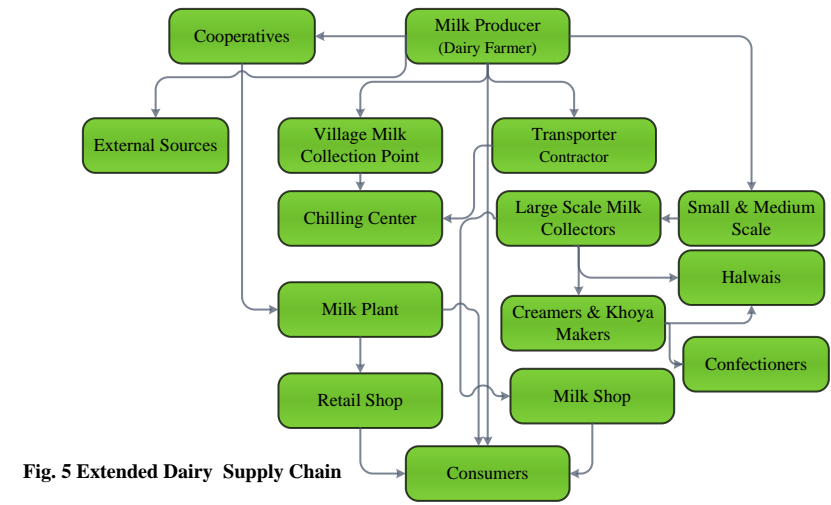

\section{b. Critical Failure of Pakistan Dairy Supply Chain}

- Poor Quality of Raw Milk

- Seasonal Milk Supply

- Poor Transport Infrastructure

- Informal Channel Adulteration and Bargaining Power of Finance and Information

- In efficiency in Implementation of Pasteurization Laws

- Milk Collection and Processing Inefficiency due to Knowledge and Technology

- Lacking Cooling Facilities

- Long Distance from Production to Consumption Locations

- Farmer's Profitability

\section{Conclusion}

Fierce competition in today's global markets and fast changes in behaviors and heightened expectations of consumers stimulates the need for efficiency in the diary firms operations. Diary supply chain play an important role in providing access to farmers in markets i.e. local, regional, national and export markets. Substantially, changes in diary supply chain system impact on the diary industrial enterprises to compete at small, medium and large scale level and to improve these firms capability of innovation make them more responsive with lowest possible costs.

Currently diary sector has been facing various challenges and one of the most critical issues is growing world population with a continually growing demand for milk and milk made products. Specifically in developing countries aging society, young, fast growing numbers of children's and urbanization have become quite challenging and generating large enough demand of milk.

It is integral for effective dairy supply chain management to establish single point of contact for partners which ensure accurate, complete, reliable, timely and continuous paramount information flow. Despite that a particular agenda is needed for collaboration and integration of dairy supply chain partners and management of supply chain power in the chain. It is extremely required to bring extensions of such project and schemes which are useful for such kind of collaborations and efficiency of dairy sector. Importantly, there is need to trust development among trading members to building long term visionary relationships. That is possible only through remove small and large barriers among the chain members. In fact operational environment of dairy sector could be strengthen through enforcement of motivating factors that are effective for chain members and to make dairy production and distribution processes more efficient in terms of duration, breadth, strength and closeness. In fact establishment and activation of new institutions, development of diary friendly policies and strategies about effective supply chain management are important to accommodate the rapid growing milk demand in Pakistan. Pakistan has enough potential to improve milk production capacity from existing species, and state can encourage farmers towards this industry by assurance of transparent strategies. We argue that there is urgent need to concentrate on the diary supply chain to avoid from wastage, economic and non-economic losses and to sustain farmers in the industry.

\section{References}

[1] Boehlje, M. (1996). Industrialization of Agriculture: What are the implications?.Choices, 11(1).

[2] Jones, T. C., \& Riley, D. W. (1985). Using inventory for competitive advantage through supply chain management. International Journal of Physical Distribution \& Logistics Management, 15(5), 16-26.

[3] Cooper, M. C. (1997). Meshing multiple alliances. journal of Business Logistics.

[4] Lambert, D. M., \& Cooper, M. C. (2000). Issues in supply chain management.Industrial marketing management, 29(1), 65-83.

[5] Daugherty, P. J., Richey, R. G., Genchev, S. E., \& Chen, H. (2005). Reverse logistics: superior performance through focused resource commitments to information technology. Transportation Research Part E: Logistics and Transportation Review, 41(2), 7792.

[6] Attaran, M. (2004). Nurturing the Supply Chain. Industrial Management, 46(5). 
[7] Leonard, L. N., \& Cronan, T. P. (2002). A study of the value and impact of electronic commerce: electronic versus traditional replenishment in supply chains. Journal of Organizational Computing and electronic commerce, 12(4), 307-327.

[8] VAN DER VORST, J. G., \& BEULENS, A. J. (1999). A research model for the redesign of food supply chains. International Journal of Logistics: Research and Applications, 2(2), 161-174.

[9] Stank, T. P., Crum, M. R., \& Arango, M. (1999). Benefits of interfirm coordination in food industry supply chains. Journal of business logistics.

[10] Lee, H. L. (2004). The triple-A supply chain. Harvard business review, 82(10), 102-113.

[11] Christopher, M., \& Ryals, L. (1999). Supply chain strategy: its impact on shareholder value. International Journal of Logistics Management, The, 10(1), 1-10.

[12] Mentzer, J. T., Foggin, J. H., \& Golicic, S. L. (2000). Collaboration: the enablers, impediments, and benefits. Supply chain management review, 4(4), 52-58.

[13] Bhagat, D., \& Dhar, U. R. (2011). Agriculture Supply Chain Management: A Review. IUP Journal of Supply Chain Management, 8(3).

[14] ZUURBIER, P. J., Trienekens, J. H., \& Ziggers, G. W. (1996). Verticale samenwerking. Deventer: Kluwer Bedrijfswetenschappen (in Dutch)

[15] Scott, C., \& Westbrook, R. (1991). New strategic tools for supply chain management. International Journal of Physical Distribution \& Logistics Management, 21(1), 23-33.

[16] Towill, D. R. (1996). Time compression and supply chain management-a guided tour. Supply Chain Management: An International Journal, 1(1), 15-27.

[17] Fearne, A. (1996) Editorial note. Supply Chain Management (1), 3-4

[18] Bryceson, K. P., \& Smith, C. (2008, February). Abstraction and modelling of agri-food chains as complex decision making systems. In presentation at the 110th EAAE Seminar on 'System Dynamics and Innovation in Food Networks' Innsbruck-Igls, Austria.

[19] van der Vorst, J. G., Da Silva, C. A., \& Trienekens, J. H. (2007). Agro-industrial supply chain management: concepts and applications. FAO.

[20] Ahumada, O., \& Villalobos, J. R. (2009). Application of planning models in the agri-food supply chain: A review. European Journal of Operational Research,196(1), 1-20.

[21] Boehlje, M. (1999). Structural changes in the agricultural industries: how do we measure, analyze and understand them?. American Journal of Agricultural Economics, 81(5), 1028-1041.

[22] Gorton, M., Dumitrashko, M., \& White, J. (2006). Overcoming supply chain failure in the agri-food sector: A case study from Moldova. Food Policy, 31(1), 90-103.

[23] Ménard, C., \& Klein, P. G. (2004). Organizational issues in the agrifood sector: toward a comparative approach. American Journal of Agricultural Economics,86(3), 750-755.

[24] Ketchen Jr, D. J., \& Giunipero, L. C. (2004). The intersection of strategic management and supply chain management. Industrial Marketing Management,33(1), 51-56.

[25] Crook, T. R., \& Combs, J. G. (2007). Sources and consequences of bargaining power in supply chains. Journal of Operations Management, 25(2), 546-555.

[26] Demeter, R. M., Meuwissen, M. P. M., Oude Lansink, A. G. J. M., \& Van Arendonk, J. A. M. (2009). Scenarios for a future dairy chain in the Netherlands.NJAS-Wageningen Journal of Life Sciences, 56(4), 301-323.

[27] Dong, F. (2006). The outlook for Asian dairy markets: the role of demographics, income, and prices. Food Policy, 31(3), $260-271$.

[28] Delgado, C. L. (2003). Rising consumption of meat and milk in developing countries has created a new food revolution. The Journal of Nutrition, 133(11), 3907S-3910S.

[29] Devlieghere, F., Vermeiren, L., \& Debevere, J. (2004). New preservation technologies: possibilities and limitations. International Dairy Journal, 14(4), 273-285.

[30] Creamer, L. K., Pearce, L. E., Hill, J. P., \& Boland, M. J. (2002). Milk and Dairy Products in the 21st Century Prepared for the 50th Anniversary of the Journal of Agricultural and Food Chemistry. Journal of agricultural and food chemistry,50(25), 7187-7193.

[31] Ma, Y., Ryan, C., Barbano, D. M., Galton, D. M., Rudan, M. A., \& Boor, K. J. (2000). Effects of somatic cell count on quality and shelf-life of pasteurized fluid milk. Journal of Dairy Science, 83(2), 264-274.

[32] Barbano, D. M., Ma, Y., \& Santos, M. V. (2006). Influence of Raw Milk Quality on Fluid Milk Shelf Life< sup> 1, $2</$ sup $>$. Journal of dairy science, 89 , E15-E19.

[33] Hotchkiss, J. H., Werner, B. G., \& Lee, E. Y. (2006). Addition of carbon dioxide to dairy products to improve quality: a comprehensive review. Comprehensive reviews in food science and food safety, 5(4), 158-168.

[34] Vermeiren, L., Devlieghere, F., Van Beest, M., De Kruijf, N., \& Debevere, J. (1999). Developments in the active packaging of foods. Trends in Food Science \& Technology, 10(3), 77-86.

[35] Kruijf, N. D., Beest, M. V., Rijk, R., Sipiläinen-Malm, T., Losada, P. P., \& Meulenaer, B. D. (2002). Active and intelligent packaging: applications and regulatory aspects. Food Additives \& Contaminants, 19(S1), 144-162.

[36] Yam, K. L., Takhistov, P. T., \& Miltz, J. (2005). Intelligent packaging: concepts and applications. Journal of Food Science, 70(1), R1-R10.

[37] Gorton, M., \& Buckwell, A. S. Davidova (2000), "Transfers and distortions along the CEEC food supply chains” in Tangermann, S., and M. Banse. Central and Eastern European Agriculture in an Expanding European Union.

[38] Dries, L., Germenji, E., Noev, N., \& Swinnen, J. F. (2009). Farmers, vertical coordination, and the restructuring of dairy supply chains in Central and Eastern Europe. World development, 37(11), 1742-1758.

[39] Elmuti, D. (2002). The perceived impact of supply chain management on organizational effectiveness. Journal of Supply Chain Management, 38(3), 49-57.

[40] Tan, K. C. (2002). Supply chain management: practices, concerns, and performance issues. Journal of Supply Chain Management, 38(1), 42-53.

[41] Handfield, R. B., \& Nichols, E. L. (2002). Supply chain redesign: Transforming supply chains into integrated value systems. FT Press.

[42] Hill, C. A., \& Scudder, G. D. (2002). The use of electronic data interchange for supply chain coordination in the food industry. Journal of Operations Management, 20(4), 375-387.

[43] Shou, Y., Feng, Y., Zheng, J., Wang, G., \& Yeboah, N. E. (2013). Power source and its effect on customer-supplier relationships: An empirical study in Yangtze River Delta. International Journal of Production Economics, 146(1), 118-128. 